Technological University Dublin

DÜBLIN

ARROW@TU Dublin

\title{
Antimicrobial Resistance in Irish isolates of Verocytotoxigenic Escherichia coli (E. coli)-VTEC.
}

\author{
Ciara Walsh \\ Technological University Dublin, ciara.walsh@tudublin.ie \\ Geraldine Duffy \\ The National Food Centre, Teagasc, Dunsinea, Ashtown, Dublin 15 \\ R. O'Mahoney \\ University College Dublin, Ireland
}

See next page for additional authors

Follow this and additional works at: https://arrow.tudublin.ie/schfsehart

Part of the Food Science Commons

\section{Recommended Citation}

Walsh, C. et al (2006) Antimicrobial Resistance in Irish isolates of Verocytotoxigenic Escherichia coli (E. coli)-VTEC. International Journal of Food Microbiology, 109, 173-178, 2006. doi.org/10.1016/ j.jjfoodmicro.2006.01.023

This Article is brought to you for free and open access by the School of Food Science and Environmental Health at ARROW@TU Dublin. It has been accepted for inclusion in Articles by an authorized administrator of ARROW@TU Dublin. For more information, please contact arrow.admin@tudublin.ie, aisling.coyne@tudublin.ie, gerard.connolly@tudublin.ie.

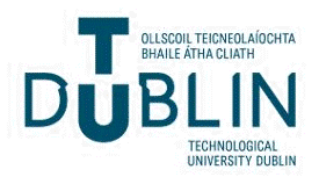




\section{Authors}

Ciara Walsh, Geraldine Duffy, R. O'Mahoney, I. S. Blair, and D. A. McDowell

This article is available at ARROW@TU Dublin: https://arrow.tudublin.ie/schfsehart/265 
In Press in the International Journal of Food Microbiology

Antimicrobial Resistance in Irish isolates of Verocytotoxigenic Escherichia coli (E. coli)VTEC.

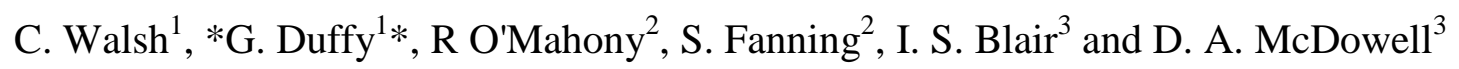

${ }^{1}$ The National Food Centre, Teagasc, Dunsinea, Ashtown, Dublin $15,{ }^{2}$ Centre for Food Safety, School of Agriculture, Food Science and Veterinary Medicine, University College Dublin, Belfield, Dublin 4, Ireland, ${ }^{3}$ Food Microbiology Research Unit, NICHE, University of Ulster, Shore Road, Newtownabbey, BT37 OQB, Northern Ireland.

*Author for correspondence

Tel.: $(+353-1) 8059500$

Fax: (+353-1) 8059550

E-mail: Gduffy@nfc.teagasc.ie 
In Press in the International Journal of Food Microbiology

\section{Abstract}

This study compared the antimicrobial resistance profiles of Escherichia coli O157:H7 isolates $(n=257)$ recovered from bovine hides, minced beef and human clinical samples in Ireland, to those profiles of a range of Irish non-O157 E. coli $(\mathrm{O} 111$ and $\mathrm{O} 26)$ isolates $(\mathrm{n}=31)$ from a variety of clinical and veterinary sources. Four multi-drug resistant (MDR) E. coli O157:H7 food isolates were identified, with resistance to 10 (1 isolate), 6 ( 1 isolate) and 4 (2 isolates) antimicrobial agents respectively. Two of these isolates (resistant to 7 and 4 antimicrobial classes) were characterised further by molecular methods and found to contain class 1 integrons along with a $\beta$-lactamase-encoding tem- 1 gene. Transfer of antimicrobial resistance (ampicillin, streptomycin and sulphonamides), the tem-1 gene and markers (int1, qacEA1, sull) characteristic of class 1 integrons were evident in one MDR isolate (resistant to 4 antimicrobial classes) when conjugation and transformation experiments were performed. A clinical isolate and a veterinary isolate of the O111 serotype were MDR and resistant to 4 and 3 antimicrobial classes respectively. These data suggests that the prevalence of antimicrobial resistance among the three VTEC serotypes examined in this study is low. These organisms may become a public health risk should they enter the food chain. 
In Press in the International Journal of Food Microbiology

\section{Introduction.}

Cattle are considered to be a reservoir host of Escherichia coli $\mathrm{O} 157: \mathrm{H} 7$ and contaminated foods of bovine origin are important vehicles of human infection. Infection can manifest itself in severe and often fatal clinical symptoms, notably haemolytic uremic syndrome (HUS), which is characterised by the simultaneous occurrence of haemolytic anaemia, thrombocytopenia and renal failure (Weir, 2000). The low infectious dose and high virulence of E. coli $\mathrm{O} 157: \mathrm{H} 7$ make infections severe and life threatening, particularly for young children, the elderly and immuno-compromised individuals.

Multi-drug resistance (MDR) is more often reported amongst non-pathogenic E. coli, compared to the pathogenic verocytotoxigenic E. coli (VTEC) organisms (Mizan et al., 2002; Sanchez et al., 2002; Bettelheim et al., 2003), independent of their source(s). Moreover, MDR-VTEC isolates reported now include both O157:H7 (Gallard et al., 2001; Fitzgerald et al., 2003) and non-O157 serotypes, [including O111, O26, O118, O103, O128 and O145] (Maidhof et al., 2002; White et al., 2002; Schroeder et al., 2002b).

The use of antimicrobials in medicine (clinical and veterinary), coupled with their application in animal husbandry (often at a subtherapeutic levels), is regarded as a potential driving force for the selection of antimicrobial resistant bacteria. The increased use of antimicrobial agents has resulted in phenotypic changes, often due to chromosomal mutation(s) or the acquisition of extraneous DNA as part of mobile genetic element(s) such as plasmids or other related structures. Integrons are another type of genetic element, which are now recognised as efficient means by which resistance genes can be acquired through in vivo recombination and subsequently disseminated. Integrons can incorporate variable sized open reading frames (ORFs), gene cassettes, that encode antibiotic resistance determinants. One or more cassettes can be recombined within an integron. In addition to the latter, integrons also contain two domains, a 5'-conserved segment (CS) encoding an int1 recombinase and a 3'-CS 
containing two ORFs, qacE $\Delta l$ (resistance to quaternary ammonium compounds) and sull (a sulphonamide resistant gene).

Increasing resistance to therapeutically valuable antimicrobial agents among pathogenic bacteria may lead to an increase risk of therapeutic failure. For E. coli O157:H7 infections, the use of antimicrobial therapy remains controversial, as these agents can lead to bacterial cell wall disruption and the eventual release of shiga toxins in vivo (Takahasdi et al., 1997; Mack, 2000). Conversely, it has been reported that certain antimicrobials may also suppress the release of these toxins, thereby preventing the onset of haemolytic uremic syndrome (HUS) (Shioma et al., 1999; Murakami et al., 2000). Any change in susceptibility of the pathogens may comprise the use of antimicrobial agents.

In this study we examined the antimicrobial resistance profiles of 288 VTEC isolates cultured from the human food production, processing, distribution and the consumption chains, [i.e. veterinary, abattoir, retail, and human (clinical) sources] in Ireland. A genetic basis for the resistance profile was established for two MDR isolates (resistant to 10 and 6 antimicrobial agents) and their ability to transfer antimicrobial resistance was investigated. 


\section{Materials and Methods}

\subsection{Bacterial Strains.}

VTEC isolates (288) examined in this study included E. coli $\mathrm{O} 157: \mathrm{H} 7$ (204) isolated from the hide of beef carcasses in Irish abattoirs (O'Brien et al., 2005), E. coli $\mathrm{O} 157: \mathrm{H} 7$ (45) isolated from Irish ground beef (Cagney et al., 2004) and clinical E. coli O157:H7 (8) obtained from a hospital in the Dublin area. In addition, this study also included non-O157 isolates, E. coli $\mathrm{O} 111$ (16) and E. coli $\mathrm{O} 26$ (15), cultured from a variety of Irish clinical and veterinary sources.

\subsection{Antimicrobial Susceptibility Testing.}

The resistance profiles of all VTEC isolates (288) were determined against a panel of 15 antimicrobial agents as described by Walsh et al., (2001), using the standardised BauerKirby agar disc diffusion technique. Lawn cultures of each isolate were prepared on Mueller Hinton Agar (Oxoid) following the NCCLS guidelines_Anon, 2004). Antimicrobial containing discs (Oxoid) used, included ampicillin (Amp $10 \mu \mathrm{g}$ ); cefachlor (Cec $30 \mu \mathrm{g}$ ); cefixime (Cfm $5 \mu \mathrm{g}$ ); chloramphenicol (C $30 \mu \mathrm{g}$ ); ciprofloxacin (Cip $5 \mu \mathrm{g}$ ); doxycycline (Do $30 \mu \mathrm{g}$ ); kanamycin (K $30 \mu \mathrm{g})$; minocycline (Mh $30 \mu \mathrm{g}$ ); moxalactam (Mox $30 \mu \mathrm{g}$ ); nalidixic acid (Na $30 \mu \mathrm{g}$ ); norfloxacin (Nor $10 \mu \mathrm{g}$ ); streptomycin (S $10 \mu \mathrm{g}$ ); sulfonamides (Su $300 \mu \mathrm{g}$ ); tetracycline (T $30 \mu \mathrm{g}$ ) and trimethoprim (W $5 \mu \mathrm{g}$ ) were carefully applied onto the lawn cultures and incubated for $24 \mathrm{~h}$ at $37^{\circ} \mathrm{C}$. Zone diameters were measured and the susceptibility (or resistance) of each isolate to the panel of agents was determined. The controls strains used were E. coli ATCC 25922 and Pseudomonas aeruginosa ATCC 27853. Any isolate was 
resistant to 3 or more different antimicrobial classes (Miragaia et al. 2002) was defined as multi-drug resistant (MDR).

\subsection{Genomic DNA isolation.}

Genomic DNA was purified from each isolate using the Wizard Genomic DNA purification kit (Promega, Madison, WI), according to the manufacturer recommendations. Following recovery of the template DNA, the corresponding DNA concentration was determined spectrophotometrically as previously described (O’Mahony et al., 2005). The integrity of the purified template DNA was assessed by conventional agarose gel [1.5\%, $(\mathrm{w} / \mathrm{v})$ ] electrophoresis in $1 \mathrm{X}$ tris-EDTA-acetic acid (TAE) buffer containing $0.5 \mu \mathrm{g} / \mathrm{ml}$ ethidium bromide (EtBr). DNA preparations were stored at $4^{\circ} \mathrm{C}$.

\subsection{PCR analysis.}

Variable regions containing the characteristic gene cassette(s) associated with class 1 integron structures were amplified, as described previously (O’Mahony et al. 2005). Primer sets and thermal cycling conditions are outlined in Tables 1 and 2 . The conserved structures of class 1 integrons, 5' - and 3'-CS domains were also assessed by PCR.

\subsection{Amplification of $\beta$-lactamase-encoding tem gene by PCR.}

Template DNA from the two MDR isolates (resistant to 7 and 4 antimicrobial classes) were examined for the presence of the tem-encoding $\beta$-lactamase, using the PCR primers and cycle conditions described in Table 1 and 2. 
In Press in the International Journal of Food Microbiology

\subsection{DNA sequence analysis of $\beta$-lactamase-encoding tem-1 gene}

Amplicons of interest were -extracted directly from the agarose gel using a QIAGEN gel extraction kit (QIAGEN, West Sussex, UK). The extracted DNA fragment was purified and quantified (as described above) and sequenced commercially (Qiagen, Hilden, Germany). Amplicons were sequenced in both directions once. Sequence text files were subsequently obtained and used to search the current GenBank databases using the BLAST suite of programs (Altschul et al., 1997). CLUSTALW amino acid sequence alignments were produced for comparison (Thompson et al., 1994).

2.6. Investigation of antimicrobial transfer from 2 MDR E. coli O157:H7 isolates (resistant to 10 and 6 antimicrobials)

Each of the 2 MDR E. coli O157:H7 (donor stains) and recipient strain of Salmonella Derby were cultured in duplicate in $10 \mathrm{ml}$ of LB Broth (Miller) for $24 \mathrm{~h}$ at $37^{\circ} \mathrm{C}$. The recipient $S$. Derby strain was previously shown to be susceptible to all antimicrobials, to which the 2 donor MDR strains were resistant. $S$. Derby did not contain the $\beta$-lactamase gene tem or a class 1 integron. The overnight cultures were centrifuged at 15,000 $\mathrm{g}$ for $3 \mathrm{~min}$ and each pellet was resuspended in $3 \mathrm{ml}$ sterile water. Each of the 2 MDR donor strains was combined separately with the $S$. Derby recipient strain in a 1:1 ratio. One hundred $\mu$ laliquots were then plated out onto 10 previously dried Tryptone Soya Agar (Oxoid) plates and incubated for $24 \mathrm{~h}$ at $37^{\circ} \mathrm{C}$. The resultant cultures were restreaked onto Xylose Lysine Desoxycholate (Oxoid), which after $2 \mathrm{~h}$ at $25^{\circ} \mathrm{C}$ was overlayed with TSA containing 100

$\mu \mathrm{g} / \mathrm{ml}^{-1}$ ampicillin and incubated for a further $24 \mathrm{~h}$ at $37^{\circ} \mathrm{C}$. Isolates of typical Salmonella 
morphology (black colony with halo) were restreaked on XLD containing $100 \mu \mathrm{g} / \mathrm{ml}^{-1}$ ampicillin and incubated at $37^{\circ} \mathrm{C}$ for $24 \mathrm{~h}$. Further confirmation tests were carried out on the resultant cultures.

Plasmid purification of the 2 MDR E. coli $\mathrm{O} 157: \mathrm{H} 7$ strains was carried out using a standard kit (Pure Link Hi Pure Plasmid Maxiprep kit, Invitrogen, USA). The resultant plasmid was then transformed into competent strains of $S$. Derby by heat shocking at $42^{\circ} \mathrm{C}$ for 2 min and followed by growth on TSA containing $100 \mu \mathrm{g} / \mathrm{ml}^{-1}$ ampicillin in accordance with Ausubel et al. (2002).

The transconjugant and transformed isolates were tested to ascertain their newly acquired antibiotic resistance profiles, by disc diffusion testing in accordance with the NCCLS standard. The DNA of these strains was once again purified and screened by PCR for the tem gene and class 1 integron associated genes as previously described.

\section{Results}

\subsection{Antimicrobial Profiles.}

The resistance profiles of the VTEC isolates examined are presented in Table 1. Four (1.4\%) of the 288 VTEC isolates tested were found to be MDR. Among the E. coli O157:H7 isolates, $2 \mathrm{MDR}$ isolates were cultured from retail mince-beef (ground beef). One was resistant to 10 antimicrobials (AmpCDoKMhNaSSuTW) belonging to 7 different antimicrobial classes and the other to 6 antimicrobials (AmpDoMhSSuT) belonging to 4 different antimicrobial classes. It was noted that considerable cross-resistance existed between tetracycline, doxycycline and minocycline. 
All remaining E. coli $\mathrm{O} 157$ isolates from hides or from clinical sources (Table 1) were not classed as MDR since they were resistant to fewer than two antimicrobial classes. Two $E$. coli $\mathrm{O} 111$ isolates examined were MDR, one clinical (AmpNaSW) and one veterinary isolate (AmpSSu). Only 2 out of 15 E. coli $\mathrm{O} 26$ isolates (clinical and veterinary) examined showed antimicrobial resistance (tetracycline), all other isolates were found to be sensitive to all the antimicrobials used in this study.

The highest prevalence of resistance in the E. coli $\mathrm{O} 157$ minced beef isolates were to the antimicrobials, streptomycin (36\% of all minced beef isolates), nalidixic acid (29\%), doxycycline (9\%) and tetracycline (9\%). None of the 45 minced beef isolates were found to be resistant to ciprofloxacin, norfloxacin and moxalactam. Similarly, the highest prevalence of resistance in E. coli $\mathrm{O} 157$ bovine hide isolates was to streptomycin (8\% of bovine hide isolates), followed by sulfonamides (6\%) and kanamycin (6\%). Streptomycin resistance was common (10\%) in the clinical isolates of E. coli $\mathrm{O} 157$ (8), O111 (7) and $\mathrm{O} 26$ (6) examined, followed by ampicillin (5\%), nalidixic acid (5\%) and trimethoprim (5\%). Clinical isolates were found to be completely susceptible to 11 of the examined antimicrobials. The highest prevalence of resistance amongst E. coli $\mathrm{O} 111$ (9) and E. coli $\mathrm{O} 26$ (9) veterinary isolates was also to streptomycin (17\%), followed by sulfonamides (11\%) and kanamycin (11\%). All veterinary isolates were found to be susceptible to 9 of the antimicrobials tested. Overall the highest prevalence of resistance in all of the 288 isolates tested was found to the antimicrobial streptomycin (8\%), followed by nalidixic acid (6\%), sulfonamides (3\%), kanamycin (2\%) and tetracycline (2\%). All 288 VTEC isolates were found to be susceptible to cefixime and ciprofloxacin.

\subsection{Investigation of $2 M D R$ isolates for resistant isolates for integrons and $\beta$-lactamase-} encoding tem-1 genes by PCR. 
In Press in the International Journal of Food Microbiology

The genetic basis for antimicrobial resistance and transfer were explored in the 2 MDR E. coli $\mathrm{O} 157: \mathrm{H} 7$ mince beef isolates (resistant to 7 and 4 antimicrobial classes). Two MDR isolates of $E$. coli $\mathrm{O} 157: \mathrm{H} 7$ (resistant to 7 and 4 antimicrobial classes) were analysed for the presence of class 1 integrons and tem-1-encoding ORFs by PCR. Data obtained showed that 2 of the minced beef MDR E. coli $\mathrm{O} 157: \mathrm{H} 7$ isolates contained class 1 associated gene cassette structure. Both MDR isolates produced an amplicon of approx. $500 \mathrm{bp}$ after agarose gel electrophoresis. These two MDR isolates were also found to contain int1, qacEA1, sull markers characteristic of class 1 integrons (data not shown). In addition, these isolates were found to contain the tem- 1 gene. The tem- 1 gene confers resistance to $\beta$-lactam agents.

Sequence analysis of the putative tem-1 gene amplified from the E. coli $\mathrm{O} 157: \mathrm{H} 7$ which was resistant to 7 antimicrobial classes, showed $98 \%$ sequence identity to tem- 1 from a Serratia marcescens isolate (accession number AB103506), a Salmonella Enteritidis isolate (accession number AB103092) and a plasmid (pINSRA99) located tem-1 gene from E. coli (accession number AJ437107). BLAST searches with the putative tem- 1 gene from the $E$. coli $\mathrm{O} 157: \mathrm{H} 7 \mathrm{MDR}$ isolate (resistant to 4 antimicrobial classes), also confirmed the presence of a tem- 1 gene in this isolate. In the latter case, this tem- 1 displayed a $97 \%$ identity to other tem-1 genes found within E. coli expression vectors such as pKM263-2xHMK (accession number AY428066).

\subsection{Investigation of antimicrobial transfer from 2 MDR E. coli O157:H7 isolates (resistant to 7 and 4 antimicrobial classes))}

The MDR E. coli O157:H7 strain resistant to 4 antimicrobial classes (AmpDoMhSSuT) transferred ampicillin resistance by conjugation with the $S$. Derby recipient strain. Ampicillin 
In Press in the International Journal of Food Microbiology

resistance was also transferred by plasmid isolation from this MDR strain and transformation into a competent $S$. Derby strain. Disc diffusion showed that resistance to streptomycin and sulphonamides was transferred on both occasions, along with ampicillin resistance.

Resistance to tetracycyline, minocycline or doxycycline was not transferred. PCR confirmed the presence of the tem gene and class 1 integron associated markers (intl, qacE $\Delta l$ and sull) in the recipient strain, which was not present in $S$. Derby prior to conjugation or transformation.

The transfer of antimicrobial resistance was not evident by mating or transformation in the strain of E. coli $\mathrm{O} 157: \mathrm{H} 7$ resistant to 7 antimicrobial classes (AmpCDoKMhNaSSuTW).

\section{Discussion}

E. coli is commonly found in the gastrointestinal tracts of humans and animals. Various selective pressures in these environments favour the development, persistence and dissemination of robust strains some of which may be resistant to antimicrobial agents (Schroeder et al., 2002a; 2002b). In this study, we observed antimicrobial resistance to several classes of antibiotics \{including $\beta$ - lactams, aminoglycosides, sulfonamides, quinolones, tetracyclines, cephems, benzene derivatives (chloramphenicol) and macrolides , and our observations are supported by those of others (Maidhof et al., 2002; White et al., 2002; Schroeder et al. 2002a; 2002b; Magwira et al., 2005), confirming that resistance to a broad variety of antimicrobials classes can occur in VTEC. Among the 288 VTEC isolates in this collection (1.4\% of which were MDR), two of 45 E. coli $\mathrm{O} 157: \mathrm{H} 7$ isolates and 2 strains of E. coli $\mathrm{O} 111$ exhibited an MDR phenotype, suggesting that MDR may be emerging across the range of VTEC (including O157 and non-O157) serotypes. This is in agreement with the literature (Schroeder et al., 2002a; 2002b; White et al., 2002), which reported a MDR E. coli 
O118:H6 isolate carrying resistance to 8 antimicrobials (Maidhof, 2002). One of the MDR isolates from this study was resistant to 10 antimicrobial agents (AmpCDoKMhNSSuTW) belonging to 7 antimicrobial classes and the other to 6 antimicrobial agents, belonging to 4 antimicrobial classes. Multi-drug resistance to six or seven antimicrobial agents has been previously reported in E. coli O157:H7 (Giammanco et al., 2002; Miwa, et al. 2002; Golding and Matthews, 2004). Detection of an isolate simultaneously resistant to 10 antimicrobials, especially from a retail meat source is a concern, as it may pose a risk to public health were these isolates to gain entry to the food chain. The therapeutic value of antimicrobial use in the case of VTEC infection requires careful consideration, however there is cautious optimism that with further research and observation, some antimicrobials be useful in the treatment of VTEC-related infections.

Further investigation was carried out on the two MDR E. coli O157:H7 strains (resistant to 7 and 4 antimicrobial classes), to identify the mechanisms responsible for resistance at the genotypic level. Both strains were found to contain class 1 integrons. These genetic structures have been previously reported in antimicrobial resistant E. coli (Du et al., 2005; Box et al., 2005) and VTEC isolates (Ahmed and Shimamoto, 2004; Ahmed et al., 2005).

A $\beta$-lactamase gene tem- 1 was identified in both MDR E. coli $\mathrm{O} 157: \mathrm{H} 7$ isolates. The tem-1 gene amplified from the E. coli $\mathrm{O} 157: \mathrm{H} 7$ resistant to 7 antimicrobial classes, showed $98 \%$ identity to a $S$. Enteritidis isolate and a similar gene located on a plasmid from E. coli and similarly the tem- 1 gene from the $E$. coli $\mathrm{O} 157: \mathrm{H} 7$ isolate resistant to 4 antimicrobial classes showed a $97 \%$ identity to other tem- 1 genes found within $E$. coli expression vectors. These results suggest that the tem- 1 is widely distributed in Salmonella and E. coli. This is in agreement with the literature, which suggests that tem-1 is the most common plasmid- 
In Press in the International Journal of Food Microbiology

mediated enzyme and confers resistance to ampicillin mainly in Gram-negative enteric organisms (Larson and Reuben, 2002).

This study showed the transfer of antimicrobial resistance by conjugation and transformation from one MDR strain of E. coli $\mathrm{O} 157$ to a Salmonella strain. The transfer of antimicrobial resistance in Enterobacteriaceae has been previously documented (Blake et al. 2003; Maisonnveuve et al. 2000; Yates et al. 2004). Singh et al. 2005 reported the transfer of antimicrobial resistance and class 1 integrons from 5 VTEC strains during conjugation. Resistance to 3 antimicrobials (ampicillin, streptomycin and sulphonamides) were transferred in this study. Similarly, Singh et al. 2005 reported the transfer of ampicillin, streptomycin and sulphonamides, among the antimicrobial resistance markers transferred during conjugation. The transfer of antimicrobial resistance (ASSu) and a class 1 integron markers during conjugation and transformation suggested that this resistance was plasmid-mediated. No evidence was found that antimicrobial resistance could be transferred from the other MDR E. coli $\mathrm{O} 157$ strain (resistant to 10 antimicrobial agents), suggesting that resistant in this instance may be chromosomal or possibly efflux pump related (Li et al., 2004). This isolate is currently the subject of further research.

The overall prevalence of antimicrobial resistance in the types of VTEC examined in this study are low, however any increase in the numbers of these isolates being reported would pose serious clinical and therapeutic challenges in the future. VTEC typically colonise the gastro-intestinal tract of ruminant animals, which is an environment with the potential for considerable gene transfer within the Enterobacteriaceae family. Multi-drug resistance among foodborne Enterobacteriaceae poses a serious challenge to all public health professionals. Vigilant surveillance of these pathogens must be a food safety priority. 


\section{REFERENCES}

Ahmed, A.M., Miyoshi, S., Shinoda S. and Shimamoto, T., 2005. Molecular characterization of a multidrug-resistant strains of enteroinvasive Escherichia coli O164 isolated in Japan. Journal of Medical Microbiology 54, 273-278.

Ahmed, A.M. and Shimamoto, T., 2004. A plasmid-encoded class 1 integron carrying sat, a putative phosphoserine phosphatase gene and aadA2 from enterotoxigenic Escherichia coli O159 isolated in Japan. FEMS Microbiology Letters 235, 243-248.

Altschul, S.F., Madden, T.L., Schaffer, A.A., Zhang, J., Zhang, Z., Miller, W and Lipmann, D.J., 1997. Gapped BLAST and PSI-BLAST: a new generation of protein database search programs. Nucleic Acids Research 25, 3389-3402.

Anon. 2004. Performance standards for antimicrobial disk susceptibility tests. In: 6th edition, Approved Standard, NCCLS document M2-A6, NCCLS: 940 West Valley Road Suite 1400. Wayne, PA. pp. 1-144.

Arlet, G. and Philippon, A., 1991. Construction by polymerase chain reaction and intragenic DNA probes for three main types of transferable $\beta$-lactamases (TEM. SHV, CARB). FEMS Microbiology Letters 82, 19-26.

Ausubel, F.M., Brent, R., Kingston, R.E., Moore, D.D., Seidman, J.G., Smith, J.A. and Struhl, K., 2002. Short Protocols in Molecular Biology: A Compendium of Methods from Currents 
In Press in the International Journal of Food Microbiology

Protocols in Molecular Biology. $5^{\text {th }}$ Edition. John Wiley and Sons Inc., Canada Unit 1-8, P129.

Bettelheim, K.A., Hornitzky, M.A., Djordjevic S.P. and Kuzevski, A., 2003. Antibiotic resistance among verocytotoxigenic E. coli (VTEC) and non-VTEC isolated from domestic animals and humans. Journal of Medical Microbiology 52, 155-162.

Blake, D.P., Hillman, K., Fenlon, D.R. and Low J.C., 2003. Transfer of antibiotic resistance between commensal and pathogenic members of Enterobacteriaceae under ileal conditions. Journal of Applied Microbiology 95, 428-436.

Box, A.T., Mevius, D.J., Schellan, P., Verhoef, J. and Fluit, A.C., 2005. Integrons in Escherichia coli from food-poisoning animals in The Netherlands. Microbial Drug Resistance 11, 53-57.

Cagney, C., Crowley, H., Duffy, G., Sheridan, J.J., O'Brien, S., Carney, E., Anderson, W., McDowell, D.A., Blair, I.S. and Bishop, R.H., 2004. Prevalence and numbers of Escherichia coli $\mathrm{O} 157: \mathrm{H} 7$ in minced beef and beef burgers from butcher shops and supermarkets in the Republic of Ireland. Food Microbiology 21, 203-212.

Daly, M., Buckley, J., Power, E. \& Fanning S., 2004. Evidence for a chromosomally located third integron in Salmonella enterica serovar Typhimurium DT104b. Antimicrobial Agents and Chemotherapy 48, 1350-1352. 
Du, X., Shen, Z., Wu, B., Xia S. and Shen, J., 2005. Characterization of class 1 integronsmediated antibiotic resistance among calf pathogenic Escherichia coli. FEMS Microbiology Letters 245, 295-298.

Fitzgerald, A.C., Edrington, T.S., Looper, M.L., Callaway, T.R., Genovese, K.J., Bischoff, K.M., McReynolds, J.L., Thomas, J.D., Anderson R.C. and Nisbet D.J., 2003. Antimicrobial susceptibility and factors affecting the shedding of E. coli O157:H7 and Salmonella in dairy cattle. Letters in Applied Microbiology 37, 392-398.

Gallard, J.C., Hyatt, D.R., Crupper S.S. and Acheson, D.W., 2001. Prevalence, antibiotic susceptibility and diversity of $E$. coli $\mathrm{O} 157: \mathrm{H} 7$ isolates from a longitudinal study of beef cattle feedlots. Applied and Environmental Microbiology 67, 1619-1627.

Giammanco, G.M., Pignato, S., Grimont, F. Grimont, P.A.D., Caprioli, A., Morabito, S. and Giammanco, G., 2002. Characterization of Shiga Toxin-Producing E. coli O157:H7 isolated in Italy and in France. Journal of Clinical Microbiology 40, 4619-4624.

Golding, S.S. and Matthews, K.R., 2004. Intrinsic mechanism decreases susceptibility of $E$. coli to multiple antibiotics. Journal of Food Protection 67, 34-39.

Larson, L.L. and R. Ramphal., 2002. Extended-Spectrum $\beta$-lactamases. Seminars in Respiratory Infection 17, 189-194. 
Lévesque, C., Piche, L., Larose, C. and Roy, P.H., 1995. PCR mapping of integrons reveals several novel combinations of resistance genes. Antimicrobial Agents and Chemotherapy, $39,185-91$.

Li, X-Z., Zhang, L. and Nikaido, H. 2004. Efflux pump-mediated intrinsic drug resistance in Mycobacterium smegmatis. Antimicrobial Agents and Chemotherapy 48, 2415-2423.

Mack, D.R., 2000. Hold the Antibiotics. The American journal of gastroenterology $95,3354$.

Magwira, C.A., Gashe. B.A. and Collison, E.K., 2005. Prevalence and antibiotic resistance of E. coli $\mathrm{O} 157: \mathrm{H} 7$ in beef products from retail outlets in Gaborne, Botswana. Journal of Food Protection 68, 403-406.

Maidhof, H., Guerra, B., Abbas, S., Elsheikha, H.M., Whittam T.S. and Beutin L., 2002. A multi-resistant clone of Shiga toxin-producing E. coli O118:[H16] is spread in cattle and humans over different European countries. Applied and Environmental Microbiology 68, $5834-5842$

Miragaia, M., Couto, I., Pereira S.F.F, Kristinsson K.G., Westh H., Jarløv J.O., Carriço, J., Almeida J., Santos-Sanches, I., and de Lencastre, H. (2002). Molecular Characterization of Methicillin-Resistant Staphylococcus epidermidis Clones: Evidence of Geographic Dissemination. Journal of Clinical Microbiology 40, 430-438. 
Maisonneuve, S., Ouriet, M. F., Duval-Iflah, Y. (2000) effects of yoghurt intake on plasmid transfer and colonisation with transconjugants in the digestive tract of mice associated with human faecal flora. FEMS Microbiology Ecology 31, 241-248.

Miwa, Y., Matsumoto, M., Hiramatsu, R., Yamazaki, M., Saito, H., Saito, M., Suzuki, Y., Miyazaki, Y., 2002. Drug resistance of enterohemorrhagic E. coli $\mathrm{O} 157$ a possible relation of plasmids to the drug resistance. Kasenshogaku Zasshi, 76, 285-290.

Mizan, S., Lee, M.D., Harmon, B.G., Tkalcic S. and Maurer, J.J. 2002. Acquisition of antibiotic resistance plasmids by enterohemorrhagic E. coli $\mathrm{O} 157: \mathrm{H} 7$ within rumen fluid. Journal of Food Protection, 65, 1038-1040.

Murakami, J., Kenji, K., Kazuhiro, H., Kazufumi, H., Yamasaki T. and Nasu M. 2000. Macrolides and clindamycin suppress the release of shiga-like toxins for E. coli O157:H7. International Journal of Antimicrobial. Agents., 15, 103-109.

O’Brien, S., Daly, D., Duffy, G., Sheridan, J.J., Blair I.S. and McDowell D.A. 2005. Prevalence and numbers of Escherichia coli $\mathrm{O} 157$ on bovine hide at a beef slaughter plant. Journal of Food Protection, (in press)

O’Mahony, R., Saugy, M., Leonard, N., Drudy, D., Bradshaw, B., Egan, J., Whyte, P., O’Mahony, M., Wall, P. and Fanning, S., 2005. Antimicrobial resistance in isolates of Salmonella spp. from pigs and the characterisation of a $S$. Infantis gene cassette. Foodborne Pathogens and Disease. Foodborne Pathogens and Disease 2, 274-281. 
Sanchez, S., Lee, M.D., Harmon, B.G., Maurer J.J. and Doyle, M.P., 2002. Animal issues associated with Escherichia coli O157:H7. Journal of the American Veterinary Medical Association 221, 1122-1126.

Schroeder, C.M., Zhao, C., DebRoy, C., Torcolini, J., Zhao, S., White, D.G., Wagner, D.D. and McDermott, P.F., Walker R.D. and Meng, J., 2002(a). Antimicrobial resistance of Escherichia coli $\mathrm{O} 157$ isolated from humans, cattle, swine and food. Applied and Environmental Microbiology 68, 576-581.

Schroeder, C.M., Meng, J.,Zhao, S., DebRoy, C., Torcolini, J., Zhao, C., McDermott, P.F., Wagner, D.D., Walker, R.D. and White, D.G., 2002(b). Antimicrobial resistance of E. coli O26, O103, O111, O128 and O145 from animals and humans. Emerging Infectious Disease $8,1409-1414$.

Shiomi, M., Togawa, M., Fujita K. and Murata, R., 1999. Effect of early fluoroquinolones in hemorrhagic colitis due to E. coli 0157:H7. Pediatric International 41, 228-232.

Singh, R., Schroeder, C.M., Meng, J., White, D.G., McDermott, P.F., Wagner, D.D., Yang, H., Simjee, S., DebRoy, C., Walker, R.D. and Zhao, S., 2005. Identification of antimicrobial resistance and class 1 integrons in Shiga toxin-producing Escherichia coli recovered from humans and food animals. Journal of Antimicrobial Chemotherapy 56, 216-219.

Stokes, H.W. and R.M. Hall, 1989. A novel family of potentially mobile DNA elements encoding site-specific gene-integration functions: integrons. Molecular Microbiology 3, $1669-1683$. 
In Press in the International Journal of Food Microbiology

Sundstrom, L, P., Radstrom, G., Swedberg and O, Skold, 1988. Site specific recombination promotes linkage between trimethoprim and sulfonamide resistance genes. Sequence characterisation of $d h f r \mathrm{~V}$ and $s u l 1$ and a recombination active locus of $\operatorname{Tn} 21$. Molecular and General Genetics 213, 191-201.

Takahashi, K., Narita, K., Kato, Y., Sugiyama, T. Koide, N., Yoshida T. and Yokochi, T., 1997. Low-level release of Shiga-like toxin (Verocytotoxin) and endotoxin from enterohemorrhagic E. coli treated with imipenim. Antimicrobial Agents and Chemotherapy 41, 2295-2296.

Thompson, J.D., Higgins, D.G. \& Gibson, T.G., 1994. CLUSTALW: improving the sensitivity of progressive multiple sequence alignment through sequence weighting, positions specific gap penalties and weight matrix choice. Nucleic Acids Research 22, 4673-80.

Walsh, D., Duffy, G., Sheridan, J.J., Blair I.S. and McDowell, D.A., 2001. Antibiotic resistance among Listeria, including Listeria monocytogenes in retail foods. Journal of Applied Microbiology 90, 512-22.

Weir, E. 2000. Escherichia coli O157:H7. Canadian Medical Association 163, 205.

White, D.G., Zhao, S., McDermott, P.F., Ayers, S., Gaines, S., Friedman, S., Wagner, D.D., Meng, J., Needle, D., Davis, M. and DebRoy, C., 2000b. Characterization of antimicrobial resistance among E. coli $\mathrm{O} 111$ isolates of animal and human origin. Microbial Drug Resistance 8, 139-146. 
In Press in the International Journal of Food Microbiology

Yates, C.M., Pearce, M.C. Woolhouse, M.E. and Amyes, S.G. 2004. High frequency transfer and horizontal spread of apramycin resistance in calf faecal Escherichia coli. Journal of Antimicrobial Chemotherapy 54, 534-537. 
TABLE 1. Antibiotic Resistance Profiles of Verocytotoxigenic E. coli (E. coli O157, E. coli $\mathrm{O} 111$ and $E$. coli $\mathrm{O} 26$ ), isolated from bovine hide, retail, clinical human and bovine veterinary sources.

\begin{tabular}{|llccl}
\hline Serotype & \multicolumn{1}{c}{ Source } & $\begin{array}{c}\text { No of } \\
\text { isolates } \\
\text { analysed }\end{array}$ & $\begin{array}{c}\text { No and \% } \\
\text { of resistant } \\
\text { isolates }\end{array}$ & R-typeI \\
\hline O157 & Minced Beef & $\mathbf{4 5}$ & $\mathbf{1}(\mathbf{2 \% )}$ & AmpCDoKMhNaSSuTW \\
O157 & Minced Beef & & $\mathbf{1}(\mathbf{2 \% )}$ & AmpDoMhSSuT \\
O157 & Minced Beef & & $2(4 \%)$ & DoST \\
O157 & Minced Beef & & $12(27 \%)$ & NaS \\
O157 & Minced Beef & & $1(2 \%)$ & CecSu \\
O157 & Bovine Hide & 204 & $2(1 \%)$ & NaS \\
O157 & Bovine Hide & & $1(0.5 \%)$ & AmpCec \\
O157 & Bovine Hide & & $1(0.5 \%)$ & AmpK \\
O157 & Bovine Hide & & $1(0.5 \%)$ & MoxSu \\
O157 & Bovine Hide & & $1(0.5 \%)$ & KSu \\
O157 & Bovine Hide & & $1(0.5 \%)$ & SSu \\
O157 & Bovine Hide & & $1(0.5 \%)$ & Cec \\
O157 & Bovine Hide & & $1(0.5 \%)$ & K \\
O157 & Bovine Hide & & $1(0.5 \%)$ & Mh \\
O157 & Bovine Hide & & $1(0.5 \%)$ & Nor \\
O157 & Bovine Hide & & $1(0.5 \%)$ & S \\
O157 & Bovine Hide & & $1(0.5 \%)$ & T \\
O157 & Clinical & 8 & $1(13 \% \%)$ & S \\
O111 & Clinical & $\mathbf{7}$ & $\mathbf{1}(\mathbf{1 4 \%})$ & AmpNaSW \\
O111 & Veterinary & $\mathbf{9}$ & $\mathbf{1}(\mathbf{1 1 \%})$ & AmpSSu \\
O111 & Veterinary & & $1(11 \%)$ & KSSu \\
O111 & Veterinary & & $1(11 \%)$ & KS \\
O111 & Veterinary & & $1(11 \%)$ & Mh \\
O26 & Clinical & 6 & none detected & none detected \\
O26 & Veterinary & 9 & $2(22 \%)$ & T \\
\hline
\end{tabular}

\section{Notes:}

II (Amp) ampicillin, (C) chloramphenicol, (Cec) cefachlor, (Do) doxycycline, (K) kanamycin, (Mh) minocycline, (Mox) moxalactam, (Na) nalidixic acid, (Nor) norfloxacin, $(\mathrm{S})$ streptomycin, $(\mathrm{Su})$ sulfonamides, $(\mathrm{T})$ tetracycline and $(\mathrm{W})$ trimethoprim

Multi-drug resistant strains (resistant to 3 or more different antimicrobial classes) are shown in bold. 
TABLE 2. Sequences and corresponding citations for oligonucleotide primers

\begin{tabular}{|c|c|c|c|}
\hline Genes & & Sequence $5{ }^{`} \rightarrow 3^{`}$ & References \\
\hline intll & $\begin{array}{l}\text { Fwd } \\
\text { Rev }\end{array}$ & $\begin{array}{l}\text { GGC ATC CAA GCA GCA AGC } \\
\text { AAG CAG ACT TGA CCT GAT }\end{array}$ & Levesque et al., 1995 \\
\hline sull & $\begin{array}{l}\text { Fwd } \\
\text { Rev }\end{array}$ & $\begin{array}{l}\text { CTT CGA TGA GAG CCG GCG GC } \\
\text { GCA AGG CGG AAA CCC GCG CC }\end{array}$ & Sundstorm et al., 1998 \\
\hline qacEAl & $\begin{array}{l}\text { Fwd } \\
\text { Rev }\end{array}$ & $\begin{array}{l}\text { ATC GCA ATA GTT GGC GAA GT } \\
\text { CAA GCT TTT GCC CAT GAA GC }\end{array}$ & Stokes and Hall, 1989 \\
\hline Tem & $\begin{array}{l}\text { Fwd } \\
\text { Rev }\end{array}$ & $\begin{array}{l}\text { TTG GGT GCA CGA GTG GGT TA } \\
\text { TAA TTG TTG CCG GGA AGC TA }\end{array}$ & Arlet and Philippon, 1991 \\
\hline
\end{tabular}

TABLE 3. Thermocycler amplification conditions

\begin{tabular}{|c|c|c|c|c|}
\hline Genes & Denaturation & Annealing & Extensions & No. of Cycles \\
\hline intll & $95^{\circ} \mathrm{C}-1 \mathrm{~min}$ & $55^{\circ} \mathrm{C}-1 \mathrm{~min}$ & $72^{\circ} \mathrm{C}-2 \min$ & 30 \\
\hline sull & $95^{\circ} \mathrm{C}-1 \mathrm{~min}$ & $65^{\circ} \mathrm{C}-1 \mathrm{~min}$ & $72^{\circ} \mathrm{C}-2 \mathrm{~min}$ & 30 \\
\hline qacEAl & $95^{\circ} \mathrm{C}-1 \mathrm{~min}$ & $55^{\circ} \mathrm{C}-1 \mathrm{~min}$ & $72^{\circ} \mathrm{C}-2 \mathrm{~min}$ & 30 \\
\hline Tem & $94^{\circ} \mathrm{C}-1 \mathrm{~min}$ & $54^{\circ} \mathrm{C}-1 \mathrm{~min}$ & $72^{\circ} \mathrm{C}-30 \mathrm{sec}$ & 30 \\
\hline
\end{tabular}

